\title{
Worlds Represented: The March of the Penguins towards the J ug of Water
}

\section{Rivera $\mathbf{M}^{*}$}

University of Antofagasta, Chile

*Corresponding author: Mailing Rivera Lam, University of Antofagasta, Chile

Received: February 09, 2021; Accepted: March 30, 2021; Published: April 06, 2021

\begin{abstract}
In the search for an understanding of the educational processes that take place in any classroom in the country and the world and that should reflect the complexity of the entire system, this educational ethnography Represented Worlds: The March of the Penguins to the Water Jug1, portrayed for two years how they experienced the transition, from third to fourth grade, two courses of students, one, in a private (private) high school and, the other, in a municipal (public) high school in the Antofagasta commune.

The hypotheses raised are related to the way in which emancipatory social representations are constructed, articulated and communicated in social mobilizations.

The ethnographic study shows the co-narrative between the events that occurred, at the national level, with which the penguin movement was conceived in 2010 and what was happening in two high school classrooms in Antofagasta.

This ethnographic construction constitutes a proposal for the design and analysis of various ways of collecting and making the voice of the actors visible and as a response to the complexity of recording and characterizing dynamic representations in the face of unfolding events. In the last decade we have continued to develop this approach to understand and characterize the cultural, natural and social contexts that surround education, and for this reason, we share this starting point below.
\end{abstract}

Keywords: Ethnography; Education; Social representations

\section{The Context}

The contextual framework of this research is situated in the educational transformations in Latin American societies that are framed in two contextual elements: the role of the State and Educational Reforms. With regard to the role of the State, at the end of the 1970s, these societies agreed on which tasks would be in the hands of the States and which would be assumed through other institutions. The second half of the eighties and the first five years of the nineties was the time to advance in the achievement of a certain proto-consensus in relation to these aspects. It was agreed with the need to change the focus of priorities regarding the tasks that would be in the hands of the nation states. The direct action of the educational systems in reference to the States was projected as a responsibility to be shared with society. The call for consultation, information and evaluation, compensation for differences and the promotion of innovation and pedagogical transformation were, instead, emphasized as functions to be fulfilled by the States. It would no longer be a matter of choosing between the teaching State and the subsidiary State, but between the dispense State and the promoting State [1,2].

While the first would become the collector and financier of market forces, the second would become the regulator and configurator of a new educational system.

In short, it moved from the old conception of the teaching State, typical of the Latin American $19^{\text {th }}$ century, to a new educating society; but recognizing that it can only become a reality thanks to an active role of the nation states now conceived as promoters, that articulate agreements to define policies, inform and compensate in solidarity; that, at the same time that they assume these tasks, they reorganize themselves to be able to define policies and fulfill them more effectively and efficiently [3].

Regarding the second contextual element to understand the educational processes in Chile, it is that like the rest of the countries of the continent, Chile lived through a military dictatorship in the 1970s; In this context, the country underwent a transition towards democracy since 1990, the year that coincided with the enactment of the Organic Constitutional Law on Education, called "the tie-up law" and which was developed in democratic governments together with the educational reform. This fact marked the social and ideological tension between what was promulgated by a military government and what was developed by later democratic governments around the representation of Chilean education.

However, according to what is postulated, the impossibility of isolating the social micro-processes from the transformations of Chilean society was visible when the students themselves produced a movement of national opposition and resistance to the habits formed by the context of the educational policies installed [4-6].

The high school students known as the "Penguin Revolution" of 2006 the name penguin refers to the black and white colors of the 
school uniforms of the schoolgirls - evidenced the existence of a plurality of hegemonies in contradiction with the changes in society Today, a plurality of relations of social symbolic hierarchy and, of course, the plurality of meaning of education for the various actors, especially for the spokesmen of this tension, the students themselves $[7,8]$.

The actions of Chilean high school students between November 2005 and June 2006 consisted of organizing at the national level and refusing to enter classes until their demands were heard. They argued that they had presented a proposal for constructive measures to the problems they faced in the school system: poor quality of education, high cost and lack of opportunities for integration into the labor market [9]. The document was delivered, in November 2005, to the authorities of the Ministry of Education and even in April 2006, they had not received a formal response. After the penguin mobilization, the government's response was the processing and approval of the General Education Law in 2009.

\section{The Ethnographic Construction}

Given the theoretical and methodological nature of the social anthropological approach, linguistic techniques of discourse analysis and process analysis of the social representations expressed in drawings and mental map graphic organizers were used that also allow exploring the divergent thinking of the participating students and teachers.

To structure this co-report, at a micro level, 61 course council classes, 28 language classes, 18 mathematics classes, and 18 teacher councils were recorded; to know the forms of communication, between students and teachers, the social relations, the symbolic events that occurred in both high schools and that were related to the social and political processes that Chile experienced in that period [2].

These results were structured in ethnographic narratives such as: "The head teacher", "Knowing the middle third", "A strike is to claim what is badly done", "I am going to program, I am going to decide and poor that I do not participate ", The discussion for change "," This high school wants to be organized but it does not come out "," It is not an obligation ... it is an invitation "," The rules are always more important "; among other narratives, in order to show how students and teachers in high school interact and critically understand each other $[1,10]$.

At a macro level of educational anthropological analysis, 47 key informants were interviewed in depth and a total of 111 mental maps were collected on two events that occurred during the development of ethnography and that had national journalistic coverage: the case of the student María Música that he rebuked the Minister of Education Mrs. Mónica Jiménez; and 109 mental maps on the case of the discussion held in the classroom by a student and her teacher at a high school in Antofagasta [11-13].

Regarding the referents of the written press, 52 files related to the Educational Reform and the crisis in Chilean education were collected [14].

\section{Results}

The main results were the records that originated the ethnographic writing on the words, pictures, sentences with which the students and teachers interact inside and outside the classroom, as for example in the course council classes; and, also, in the extracurricular activities that constitute the rituals that these actors understand, construct and practice.

We have selected two examples of local ethnographic observation and two national newsworthy events that summarize the environments, themes, and communication dynamics that characterize the observed subsystems.

The first observation refers to the meaning of mobilization in the municipalized high school and the second addresses the way in which an academic activity is represented in the private high school.

The news events occurred in the country during this ethnography, the first was carried out by a schoolgirl and the minister of education, and, the second, occurred in a civic education class, both allow to reference an approach of the macro and the micro of the school system, respectively.

\section{A "strike" is to claim what is wrong}

The municipalized third year did not escape the national and regional context of mobilizations in education, during 2008 university students, teachers and schoolchildren called marches and mobilizations -which in the case of the city of Antofagasta- ended with destruction in high schools, incidents in the marches and a continuous stoppage between the months of May and June of that year. There was a hostile climate in the educational system caused by the processing and subsequent approval of the General Student Law, in the Senate of the Republic of Chile, which according to educational actors did not represent the improvement of education.

On May 23, 2008, the math teacher did not attend the class that I was going to observe and the course was without a teacher, in the room, when a disorder broke out in the high school across the street, they climbed on the tables to look through the windows that overlook a central street that separates both high schools. On that occasion I saw that an inspector called them to order with a challenge, daring them to dare to leave the school.

During recess, a teacher told me that during the demonstrations "various events occurred" and that external agents established different communications with the students.

The following Monday, in the course council, there was a discussion between the head professor and the students about what the strikes and the Organic Constitutional Law on Education mean.

In this discussion it can be seen that the stoppages represent, for the students, ways of claiming what is fair enough, if they are listened to, or, the hard way if they are ignored. That it is claimed for something that is badly done and that, for this reason, people do not want to do something that is badly done in this case in education. But that, nevertheless, adults do not listen.

Then the students show him with concrete examples that he, as an adult, does not listen to them either. The examples are recurring themes of complaint, by the students, in the course council: the paintings with landscapes that adorn the room were put up by the head teacher and the students complain that they are disturbed 
because they do not correspond to a classroom. professional technical specialty, the deteriorated infrastructure of the building, the subsidy that the high school receives for attendance, the penalties for attendance if the students abide by the strikes, the criticisms of the Organic Constitutional Teaching Law, the lack of communication with the head teacher, the way the head teacher sanctions the course, the actual number of lunch cards. And the constant perception of the students that the head teacher always wins in discussions.

For the head teacher, "unemployment" represents not going to class and that currently constitutes a crowd response. Regarding the paintings with landscapes, the teacher thinks that they project a suggestion of how they could decorate their houses in the future and that they can occupy the walls of the room if they keep them clean, that they remind him of the things and the agreements that he forgets. Other issues such as cards for lunch and the demarcation of responsibilities in the information of the procedures in the high school, are not clarified.

\section{It is not an obligation ... it is an invitation}

I arrived at the room and was waiting for the academic director to speak with the course regarding the secular solidarity campaign, the head professor apologizes for the absence of the course and promises to find him. I accompany the head professor to look for the course, nobody knows where he is because, in the previous class, the professor did not attend, the professor goes through different pavilions, opens and reviews different rooms, but cannot find them. We return to the room and a few students have entered and then the rest of the course appears and they enter resignedly. In the search for the course, half the hour of the course council was lost.

The academic director explains to them that she needs volunteers to serve a solidarity dinner in which they will learn notions of tourism and hospitality that will help them to work, for a fee, when they are university students. The head teacher clarifies that "it is not an obligation but an invitation" and finally, the director after promoting the dinner tickets congratulates them for signing up to collaborate.

\section{Recurrent social representations among the students of both high schools}

The students of the municipalized high school describe an education problematized by the State and by a government that does not understand them, however, they value the opportunity that education means to them, although this means being in a dead-end situation because they must study in a system in which they have no voice or visibility.

On the other hand, interaction with Peruvian immigrant students allows them to compare educational systems, from the perspective of immigrants, Chilean education is more open and Peruvian education is different because students have a passive role due to their silent personality.

From the perspective of Chilean students, in general, they value their Peruvian classmates because they dare to participate and present their own points of view; this is because the course president is a foreigner.

Strikes are seen as protest actions for things that are wrongly done and that therefore the students do not want to do, such as the insufficiency of food grants and the poor quality of the classes in the humanistic scientific area compared to the classes; very good level in the area of technical drawing specialty.

The municipalized high school is described as an institution that tries to act in an organized way but does not succeed because the excess of restrictive norms and the lack of information do not allow it, for this reason they repeatedly compare the high school to a boarding school since they feel trapped, restricted, isolated of society and incommunicado.

The head teacher is seen as a person who thinks differently from the students since he generally opposes the initiatives of the students with regard to school or recreational activities without looking for alternatives that allow the students to express themselves.

The students affirm that the role of the head teacher is to help with a heavy hand, in this aspect it is striking that even when they describe situations in which symbolic violence and authoritarianism are exercised, for example, in the verbal abuse of teachers in classes when their questions are not answered or when their contributions or comments are not incorporated into the development of the class these students recognize or attribute -in these situations- the intention of the teachers to help.

The lack of student leadership is perceived as a consequence of the constant rejections they receive from the school system, for example, when they have initiatives of activities to be carried out in the classes or in the course council and these are rejected without looking for alternatives that allow them to feel good and listened to as a course. They also describe the different interactions that they have experienced in the course, many times, participating in groups of friends and as they have grown and got to know each other, they have integrated with other classmates. However, they recognize that they are organized into groups according to behaviors that group them as calm and disorderly, this concept of the group is striking, which implies a warlike connotation of confrontation according to the confrontational context in which they interact daily with teachers and with the school system in general.

Maturity is associated with the order and clarity of the future project that they want to develop as people, for this reason the projections of the students, in general, are to do the internship, graduate, go to a pre-university, work and study and go to university.

The students of the private high school, on the other hand, perceive that the education they receive is good and refer to the evolution they have had from third to fourth grade as a transition from interacting from their own groups of friends in the course to being able to unite with the students. Other colleagues. But that, finally, the groups prevail and are identified by all.

The representations about education mainly describe the environment or relational climate with the head teacher with whom they do not feel identified because he does not play it for them, that is, he does not defend them in everyday situations such as supporting them to obtain the authorization of the school In activities proposed by them, neither does he defend or represent them before the attorneys-in-fact or before the school. For the latter, there is a fraternal relationship between the teacher, the school authorities and the 
parents, in which the head teacher only limits himself to denouncing or betraying the students without mediating communication strategies and conflict resolution. Finally, the students pigeonhole the head teacher in the role of molding the students according to what the school demands.

The pressure that students experience is related to the excess of evaluations and measurements to which they react by discriminating which evaluations or activities serve them to enter the university and which do not, according to this the students respond positively to academic motivations outside the school, such as going to college. Another motivational aspect that moves these students to action are social relationships with solidarity or just recreational goals.

It is striking that both the evaluative pressure and the social interaction are openly promoted by the school without mediating an integrating scheme of these dimensions, which would allow the academic orientation of the students' abilities without facing them as options only programmed by the school.

The problems that students face in school are the expectations of academic performance to achieve future professional goals and in the daily interpersonal relationships and the financing of social and recreational activities.

In summary, the students of both high schools have communication problems with their head teachers. In the municipalized system, the tension of the educational system comes from state and governmental decisions and the students are recognized as invisible to the system with respect to the relations in the high school, the degree of participation and expression is limited by the authoritarianism of the head teacher. However, this context does not limit the projection of carrying out their technical-professional practices, insertion in working life and entering the university because they recognize in the educational system the only possibility of being visible and existing for society.

In the private school the tension is caused by the bad relationship with the head teacher and by the pressure exerted by the school through constant evaluations. However, the motivation of life projects crosses the border of the high school, they have expectations of university professional development and an active social life. In this context, the relational figure of the head teacher is only limited to an ineffective whistleblower role before the high school authorities and the parents.

At this point, the cases presented below constitute references of the visions of the educational system.

\section{Case $\mathrm{n}^{\circ}$ 1. María Música and the Minister of Education}

What happened in Santiago on July 14, 2008 when the 14-yearold high school student María Música Sepúlveda threw a jug of water in the face of the Minister of Education, Mónica Jiménez. The event occurred on the closing day of the participatory dialogues for public education "Chile thinks public education" held at the Crowne Plaza hotel, which convened university students, schoolchildren and teachers on issues such as the General Education Law.

\section{Representations on referential cases}

The students of the municipalized high school think that the action of María Música was good because they do not listen to her, but that this action does not solve things.

The students of the private high school think that the action was negative because María Música did it to attract attention because the minister does not support her. That it represents the student community in a bad way, that it has a bad influence, that the students will be less considered with such an action and that, although the project (General Student Law) is bad, it does not justify the action.

The teachers of the municipalized high school think that María Música is a poorly educated, disrespectful, aggressive student who is spoiled by her mother. The Minister of Education represents the stubbornness of the State and stubbornness. And that incredibly there is no respect for authority.

The teachers of the private high school think that the causes of this fact are the immaturity of María Música and her intolerance to non-immediate attention; and the intransigence of the authorities. And that this fact expresses the inequality of opportunities for the youth, an unconstructive impetus and an unusual bad education. They believe that for some it is a way of demanding rights.

Regarding the facts: The students of the private high school affirm that the minister was attacked by the anger of an unheard student.

The teachers of the private high school affirm that it is a political situation that expresses the discomfort over the actions of the national educational system, the government has not complied with education, it reflects the poor quality of education in Chile where everyone thinks how bad it is and nobody offers solutions. And that the family and the country's system have the floor.

\section{Case $\mathrm{n}^{\circ} 2$. The recorded discussion of the Professor Instituto Superior de Comercio, Antofagasta}

This case occurred during an Economics class at the Antofagasta Higher Institute of Commerce, on August 4, 2008 when a discussion recorded with the cell phone of an abused student in said class was broadcast in the press and communication media. In the discussion, the teacher criticizes the third-year student, Stefany Gatica, for receiving social benefits as a single mother.

The students of the municipalized high school think that the teacher treated the student very badly in front of his classmates, that they should fire him, that he should not have spoken hurtful things without knowing the student's life, that the subsequent regret is not valid, that he should knowing how to treat students and that they cannot continue to practice. Another position is one of those who think that the teacher put up with the student and ran out of patience because the student provoked it. And that both need more communication and are responsible for the fact.

The students of the private high school think that there are different opinions on the part of teachers and students, that there is misunderstanding and that someone will have to give in. That there must be mutual respect regardless of the level of education you have. They think that the teacher acted horrible, improperly, that he should be punished and that he has no right to psychologically mistreat the student. And they think that the high school is bad and rude. 
The teachers of the municipalized high school think that this fact is a faithful reflection of the educational reality of the municipalized high schools. They think that teachers have no support, are out of control, without support and that a teaching carried out under these conditions violates the value ideals of education. They think that there should be control and respect on the part of the teachers, even if the students take them out of context.

The teachers of the private high school think that technology allowed this specific situation to come to light and that the use of technology in classrooms should be regulated. They think that being a teacher requires living in balance, peace and inner harmony and that the teacher's ideals decline when they see the sad reality of Chilean education.

\section{Conclusions}

The anthropological perspective shows the results from the meanings that students and teachers assigned to Chilean education in the context of a social movement that questions the laws, procedures and changes introduced to the educational reform of 1990, for this reason this ethnography contributes. Elements for the discussion of the current problem: the tensions of Chilean education not yet resolved [15-17].

In accordance with the foregoing, the need to develop educational ethnography as a form of construction of educational memory that bases political and economic decisions that allow "seeing", "listening" and "understanding" real subjects and situations is stressed of education, to future citizens who will continue the task of deciding and developing Chilean education [18,19].

Our ethnographic design allowed to generate knowledge and understanding of the macro-social processes that are reflected in the micro-social processes of the high schools through the analysis of the discourses that the invisible and invisible pedagogies develop [20,21]. And that in accordance with the hypotheses raised at the beginning of our research, on the construction, articulation, forms and character of the social representations of Chilean education, from the perspective of the investigated actors:

- $\quad$ Social representations about education would be built from a complex relationship between communicative practices, social relationships, rituals and meanings. These representations with deep roots in time are not fixed and would be re-invented in the historical course and in the dominant political and socio-economic frameworks $[4,7-13]$.

- The elements that articulate the social representations about communicative practices, social relations, rituals and meanings would be cultural codes that would demarcate a social and political space of the educational community.

- The forms of communicative practices, social relations, rituals and meanings of the educational community, in the context of the critical transformations of Chilean education, would respond to the way in which these processes are conceived in the school organization.

- The actors of the school organizations would externalize, through their speeches, emancipatory social representations with respect to those emanating from the State and the educational policies that define them; in the context of the Chilean education crisis.

As a consequence, in the last decade, there have been new stoppages of teachers and students because the underlying problems in education have not yet been solved.

In this context, it is worth noting that several of the student leaders of this movement became professionals and politicians who continue to disseminate these proposals.

Finally, and with regard to the proposed ethnographic design, we recognize the need to generate new applications of this approach that complements the analysis of the social representations collected through interviews, questionnaires, conversations, ethnographic observations and mental maps. Since its anthropological, social, cultural, discursive and cognitive dimensions allow to form an image and a voice - quite vivid - of what we saw, felt and heard when we walked, for the first time, the corridors of these two high schools, ethnographically portrayed; for our reflective and critical gaze.

This methodological proposal has allowed us, in the last decade, to address different educational scenarios, making visible, for example, from the natural and geographical context human adaptation to extreme climates, ethnic approaches, inclusion and learning, among others, however, the starting point of the acquired experience was this doctoral thesis [16].

Additional Information Rivera M (2010) Ethnographic study on social representations in communicative practices, social relations, rituals and meanings in secondary education, in the context of the Chilean educational crisis. Arica: Doctorate in Anthropology, Universidad Catolica del Norte - Universidad de Tarapaca, Chile.

\section{References}

1. Banchs M. Processual and structural approaches to the study of social representations, Mc Graw Hill: Madrid, Spain. 2000.

2. Baeza Correa J. Make the young person visible in the school culture, bibliographic approach to the necessary step from the role of student to the office of the student. ICET World Education Assembly. 2002: 1-17.

3. Braslavsky $\mathrm{C}$ and Cosse $\mathrm{G}$. The current educational reforms in Latin America: Four actors. Three logics and eight tensions. PREAL.

4. Ministry of Education, MECE Program (Nineteen ninety five). The school inside. Ethnographic study on work practices in secondary education. Santiago: MECE program of secondary education.

5. UNESCO. Understand what is the quality of education. Monitoring report on education for all in the world 2005. UNESCO. 2008.

6. UNESCO. Regional overview Latin America and the Caribbean. Education for all in 2015. 2018.

7. De la Rosa. Social memory, national identity and social representations: are they convergent constructs? A study on the European Union and its member states with a look at the past. 1996.

8. Domedel A \& Peña and Lillo M. The May of the penguins. Radio Universidad de Chile: Santiago, Chile. 2008.

9. Cox C. The effort to reform the school system. Points for a teaching reflection. Analysis and Challenges of the Chilean Educational Reform. 2001: 9-21.

10. Guber R. The metropolitan savage. Reconstruction of social knowledge in field work. Paidos. Buenos Aires, Argentina. 2004.

11. Marton F and Booth S. Learning and awareness. Mahwah, NJ: Lawrence Erlbaum. 1997.

12. Marton F and Morris P. What matters? Discovering critical differences in 
classroom learning. Acta universitatis Gothoburgensis: Goteborg, Sweden 2002.

13. Marton F, Rumson $U$ \& Tsui BM. The space of learning. Classroom discourse and the space of learning. 2004: 3-40.

14. Pereira de Sá C. Central nucleus of social representations. Voices: Petropolis. 1996.

15. Moscovici S \& Farr R. Social repretations. Cambridge University Press: London, England. 1984.

16. Pang MF. Making learning possible: the use of variation in the teaching of school economics. Unpublished doctoral dissertation. University of Hong Kong: Hong Kong, China. 2002.

17. Pang MF. Two faces of variation: On continuity in the phenomenographic movement. Scandinavian Journal of Educational Research. 2012: 145-156.

18. Pong WY. Widening the space of variation: Inter-contextual and intracontextual shifts in pupils' understanding of two economic concepts. Hong Kong: Unpublished doctoral dissertation, University of Hong Kong: Hong Kong, China. 2000.

19. Restrepo Bernardo. Specialization in theory, methods and techniques of social research. Research in education, module 7. Editores Arfo: Colombia. 2002.

20. Will we reach the goal? EFA Global Monitoring Report 2008. UNESCO. 2008.

21. Woods P and Hammersley M. Gender, culture and ethnicity at school. Paidós: Madrid, Spain. 1995. 